\title{
The strategy for improving the competitiveness of SMEs apple chips in Malang Raya by using the concept of the house model
}

\author{
${ }^{1 *}$ Novia, C., ${ }^{2}$ Santoso, I., ${ }^{3}$ Soemarno, S. and ${ }^{2}$ Astuti, R. \\ ${ }^{1}$ Departement of Informatics Engineering, Faculty of Engineering, Nurul Jadid University, Probolinggo, \\ East Java, Indonesia \\ ${ }^{2}$ Department of Agro Industrial Technology, Faculty of Agricultural Technology, Brawijaya University, \\ Malang, East Java, Indonesia \\ ${ }^{3}$ Department of Soil Science, Faculty of Agricultural, Brawijaya University, Malang, East Java, Indonesia
}

\section{Article history: \\ Received: 4 May 2020 \\ Received in revised form: 18 \\ May 2020 \\ Accepted: 31 May 2020 \\ Available Online: 7 July 2020}

\section{Keywords:}

Competitiveness,

Apple chips SMEs,

The house model

DOI:

https://doi.org/10.26656/fr.2017.4(5).207

\begin{abstract}
Apple chips SMEs in Malang Raya play an important role in national economic growth. The present study was aimed to analyze the strengths, weaknesses, opportunities with threats, and determine the strategy of increasing the competitiveness of apple chips SMEs in Malang Raya. The research location was in Malang Raya area consists of Malang Regency, Malang City, and Batu City. Data collection was obtained from thirty-one respondents who were owners of apple chips SMEs in Malang Raya. The data analysis technique used in this study was a SWOT analysis to analyze the strengths, weaknesses, opportunities and threats on the house model concept to determine the strategy to increase the competitiveness of apple chip SMEs in Malang Raya. The SWOT analysis showed that the business position of the apple chip SMEs are in the strength-opportunity strategy quadrant which includes, improving the quality of the apple chips, adding variations of apple chips products, extending the validity period of the home industry production permit and halal certificate if it has expired, as well as increasing the number of apple chips production. The results of the main performance index weigh for the pillar positions of the house model on the strategy of increasing competitiveness for product variables at 0.726 , human resource improvement variables at 0.198 , and marketing institutional variables at 0.076 .
\end{abstract}

\section{Introduction}

Small and medium enterprises (SMEs) have an increasingly important role in the economic growth of most countries. SMEs is considered to play a quite big role when looking at the economic resilience of large SMEs in several parts of the world (Kalpande et al., 2015; Purwidianti and Rahayu, 2017). SMEs have a very important role as a source of work and maximize the efficiency of resource allocation and distribution by mobilizing and utilizing human resources and local raw materials (Cunningham and Rowley, 2007). SMEs can also act as suppliers of goods and services for large companies. Most SMEs have been able to move dynamically, innovatively, efficiently and their small size allows flexibility, direct feedback, short decisionmaking chains, better understanding, and faster response to customer needs (Singh et al., 2008; Idar and Mahmood, 2011). Wiesner and Millett (2012) state that apart from strong contributions, SMEs remain vulnerable to changes in the economic atmosphere. It is evident that many SMEs have a short life and unstable and its existence many do not achieve long-term, even fewer achieve substantial growth.

SMEs develop in processing local raw materials, one of which is processed apple SMEs. Malang is one of the regions in Indonesia which is the center of apple production. Malang Raya has 2 apple production centers namely Batu and Poncokusumo (Rahaju and Muhandoyo, 2014). One of the processed apples produced by SMEs is apple chips. Apple chips are processed snacks made from apples that are most indemand by consumers because they are typical souvenirs of Malang City (Mallini et al., 2015). The Malang region is also a potential market for the apple processed industry because Malang is one of the best tourist destination areas. Many tourist attractions in Malang are often visited by domestic and foreign tourists. Natural, historical, and cultural tourism can be enjoyed in Malang 
(Soseco, 2015).

The development of the fruit chip industry requires business players to continue to improve the competitiveness of the products they produce in the competitive global market. Production of the apple processing industry is currently still largely dependent on market demand. During holidays, market demand will increase, but demand decreases during normal days so that many industries reduce the amount of production due to reduced market demand (Wati et al., 2014). Consumer demand sometimes can not be fulfilled by apple processed companies due to limited inventory in the finished product warehouse during the holiday season (Syam et al., 2014). The number of SMEs that are engaged in the same field and produce the same products, requires that SMEs can compete so that businesses run long-lasting.

Bahri (2012) states that competitiveness is the ability to produce goods and services that meet the test of international competition. Porter (2003) argues that national competitiveness is seen as a macroeconomic phenomenon related to the exchange rate, interest rate, and government deficit variables. If competitiveness is directed by government policies (protection, promotion of imports, and subsidies) it will push the industry into global excellence. Intense competition in the business becomes the main challenge for the company in carrying out its production activities. Companies are required to think creatively and have a competitive strategy by producing goods/services that are quality, cheap, and fast compared to competitors (Munawir et al., 2016). Increasingly high competition in the food business, the interdependence between companies incorporated in a network the stronger (Anatan, 2010). A competitive advantage occurs when a company has a product or service that is better than its competitors. The competitive power model has also changed in the internet era because companies not only compete with each other in the same industry but they also compete as part of an industry unity (Bohari et al., 2013). This study was aimed to analyze the strengths, weaknesses, opportunities with threats and determine the strategy of increasing the competitiveness of SMEs apple chips in Malang Raya.

\section{Materials and methods}

This research was conducted in the Malang Raya area which included; Malang Regency, Malang City, and Batu City. Data collection was carried out on 31 respondents who were the owners of Apple Chip SMEs in Malang Raya, consisting of 5 apple chip SMEs in Malang Regency, 6 apple chip SMEs in Malang City, and 20 apple chip SMEs from Batu City. The data analysis technique used in this study was SWOT analysis that was used to analyze the strengths, weaknesses, opportunities, and threats to Apple Chip SMEs in Greater Malang as well as the house model method used to determine the strategy to increase the competitiveness of apple chips SMEs in Malang Raya. Research instruments in the compilation of the house model include referring to the results research of Tsurayya and Kartika (2015), namely: products (product quality and price), improvement of human resources (increasing achievement, income, and skills) as well as institutional and marketing (increasing the number of partners, total market assistance and access). Horovitz and Corboz (2007) stated that The house model is a concept that was built in describing the efforts of organizations to turn dreams into actions and divided into three components, namely the roof as a vision where the vision in this study is to improve the competitiveness of apple chip SMEs, pillars as the key to achieving this vision, and the foundation of supporting behavior.

\section{Results and discussion}

\subsection{SWOT analysis}

SMEs rarely employed the SWOT analysis tool, but SMEs aware of the many factors in specific functional areas that affect their efforts to achieve business goals (Wiid et al., 2015). Factors can be identified in the SWOT analysis. SWOT analysis is a tool used for strategic planning and strategic management in organizations. it can be used effectively to build organizational strategies and competitive strategies (Gürel and Tat, 2017).

The coordinates of the SWOT diagram are determined by calculating the difference between the strength and weakness scores (as the $\mathrm{X}$-axis) and the difference between opportunities and threats (as the Yaxis). The results of the SWOT analysis are described in the SWOT diagram, which shows which business position of apple chip SMEs is in which quadrant and has implications for the general strategy that must be carried out. Business strategies that must be carried out according to quadrant positions I, II, III, IV are, respectively, a specialized, diversified, sustainable, and development (Rangkuti, 2016). Figure 1 shows the quadrant position of the SWOT analysis results.

Figure 1 shows the quadrant of the SWOT analysis of the position of apple chip SMEs in quadrant 1, namely, strength is greater than weakness. Rangkuti (2016) this quadrant is a very favorable situation. SMEs have opportunities and strengths so there needs to be an emphasis on SO strategies. SO strategy, the best strategy 
to use strength in exploiting opportunities is 1) improving the quality of apple chips, 2) increasing the variety of apple chip products, 3) extending the validity period of the home industry production permit and halal certificates if they have expired, 4) increasing the amount of apple chip production. The results of the SWOT analysis in this study aim to develop a SO, WO, ST, and WT strategy. The results of the SWOT matrix analysis in this study are shown in Table 1.

Food product quality has a direct positive effect on customer satisfaction (Canny, 2014; Nasir et al., 2014), especially if the management of the quality of food products varies greatly (Um et al., 2017). The priority of technical responses to improve product quality attributes is improving the storage process, maintaining proper machinery and equipment (Astuti et al., 2020), product quality also has a positive and significant effect of

Table 1. SWOT analysis matrix

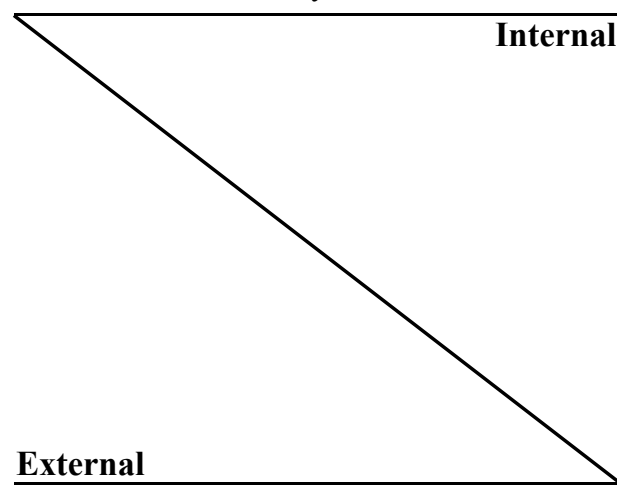

Opportunities $(\mathrm{O})$

1. Raw materials are easy to obtain

2. Improved economic growth

3. Advances in technology and information

4. Government policies that encourage the progress of SMEs

5. Potential market share

6. Increasing demand for apple chip products

\section{Threat (T)}

1. Increasing production costs, due to uncertainty in the price of raw materials and supporting materials

\section{New competitors}

3. Consumers are price-sensitive

4. New products of a more innovative type

5. Increased transportation costs

6. Limited market segment purchasing decisions (Santoso, 2016). One of the food quality concepts that is currently a trend is the quality of food that already has the halal certification. Halal certificates can also show that products are of high value (Nasirun et al., 2019). Many Islamic societies consider

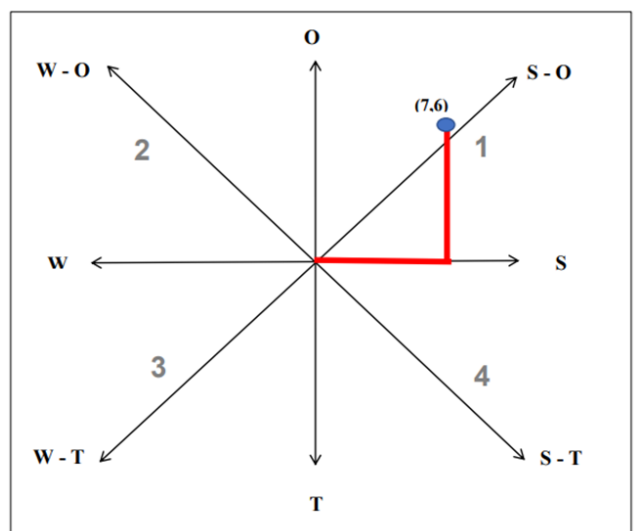

Figure 1. Quadrant of the SWOT analysis results

Weakness (W) Strength (S)

1. Absence of human resource training 1 . Having a quality product programs

2. Apple chips SMEs continue to innovate products

3. Limited distribution area

3. Competitive price

4. Not achieving sales targets

4. Good cooperation between employees

5. The level of education of employees is 5 . the home industry production has relatively low permission

6. Limited capital for the development of 6 . Earnings growth and sales increase WO Strategy (Overcoming weaknesses to SO Strategy (Using power to take seize opportunities) advantage of opportunities)

1. Provide opportunities for employees to improve their skills by holding training to always be ready in facing technological

1. Improved quality of apple chips advancements and information

2. Use technology and information advancements for product promotion so that sales targets are achieved

3. Cooperating with government and related institutions regarding capital limitations

2. Add variety to apple chip products

3. Extend the validity period of the home industry production permits and halal certificates if they have expired

4. Increase the amount of apple chip production

WT Strategy (Overcoming weaknesses to ST Strategy (Using power to overcome anticipate threats) threats)

\section{Evaluate prices regularly}

2. Increased promotional activities to expand market segments

3. cooperating with expedition services to reduce transportation costs

4. Develop SMEs by increasing the quality of HR skills
1. Improving product quality with regular machine maintenance

2. product innovation in order to survive with competitive competition

3. Increase cooperation between employees to minimize work conflicts that can disrupt the course of production

4. Meet the applicable requirements both permits and packaging for food products 
halal certificates as an important factor influencing desires in purchasing (Ali et al., 2017). Moi et al. (2016), government and industry have a very important role in improving the competitiveness of national and international halal industries.

\subsection{The house model}

This model can be used as a reference in carrying out the development process to support a strategy to increase competitiveness. This is because, in this model, specific factors and actions in supporting the determination of vision within a certain period of time can be clearly illustrated. In addition, actions supporting the success of the vision are also not limited in its development (Ananda et al., 2016). The hierarchy in the strategy to improve the competitiveness of apple chip SMEs based on each variable and its indicators is shown in Figure 2.

Figure 2 shows that there are three variables to improve the competitiveness strategy of SMEs apple chips in Malang Raya, namely; 1) product, 2) human resources (HR), and 3) institutional and marketing. While the indicators include; 1) product quality, 2) selling price, 3) customer satisfaction and loyalty, 4) improvement and development of employees, 5) achievements, 6) teamwork, 7) support of educational and training institutions, 8) improvement of marketing, institutional networks, and partners, 9) Government and private assistance, 10) expanding marketing areas, and 11) Promotion

The results of the analysis of priorities and weights on the three variables are shown in Table 2, while the indicators are shown in Table 3 . The priority of the strategy is determined from the alternatives chosen based on criteria, sub-criteria, and strategies that are considered more important to the achievement of targets, which are obtained based on expert opinion (Evalia, 2015).

Table 2 shows the results of the variable weights competitiveness of products is the first priority with a weight of 0.726. Improvement of HR occupies the second priority with a weight of 0.198 , while marketing Institutions in the third priority with a weight of 0.076 .

Table 2. Priority results and variable weights competitiveness

\begin{tabular}{lcc}
\hline Variable & Weight & Priority \\
\hline Product & 0.726 & 1 \\
HR & 0.198 & 2 \\
Institutional and Marketing & 0.076 & 3 \\
\hline
\end{tabular}

Table 3. Priority results and indicator weights on the competitiveness variable

\begin{tabular}{lcc}
\hline Indicators & Weight & Priority \\
\hline Product quality & 0.322 & 1 \\
Competitive selling prices & 0.223 & 3 \\
Consumer satisfaction and loyalty & 0.232 & 2 \\
Employee improvement and & 0.011 & 9 \\
development & 0.007 & 11 \\
Achievement obtained & 0.034 & 6 \\
Teamwork & 0.015 & 8 \\
Support education and training & & \\
institutions & 0.024 & 7 \\
Increased marketing, institutional and & \\
partner networks & 0.01 & 10 \\
Government and private assistance & 0.088 & 4 \\
Expanding the marketing area & 0.036 & 5 \\
Promotion &
\end{tabular}

Table 3 shows the results of the indicator weights on the variable Competitiveness ability to meet product quality is the first priority with a weight of 0.322 . The ability to meet satisfaction to get customer loyalty occupies the second priority, while the third priority with a weight of 0.223 is having the ability to determine selling prices that can compete with competitors. Expanding the marketing area of apple chips until leaving Malang Raya is an ability that must be owned by SMEs occupying the 4th priority with a weight of 0.088 and the $5^{\text {th }}$ priority with a weight of 0.036 is the ability to carry out promotional activities. Working together the internal team is a priority to 6 with a weight of 0,034 . An



Figure 2. A hierarchy of strategies to improve the competitiveness of apple chip SMEs 
increasing number of institutional marketing and partner networks is likely included into priority to 7 with a weight of 0.024 . Support for $8^{\text {th }}$ priority education and training institutions with a weight of 0.015 , Increasing the development of $9^{\text {th }}$ priority employees with a weight of 0.011 . Government and private aid is the 10th priority with a weight of 0.010 and the last priority is 11 th with a weight of 0.007 .

Gagić et al. (2013) found that food quality is a major contributor to customer satisfaction. Sahara and Gyau (2014), price satisfaction and loyalty are important concepts in marketing and are widely applied in the agricultural food sector. Hansen (2016) show that fairness, reliability, and relative prices are the dimensions of price satisfaction that affect producer confidence in buyers. Osman and Sentosa (2013), trust between producers and buyers were found to be a strong mediator between price satisfaction and producer loyalty. The mediating role of trust between customer price satisfaction and customer loyalty is also recognized in the business-to-customer study.

Table 4 shows the results of the main performance indicators at the product level are the increase in product quality, competitive product prices with competitors, increase in customer satisfaction and loyalty. Results key performance indicators in HR repair is increased skills of employees, increasing both personal and institutional achievements, increase in team collaboration capabilities for SME revenue improvement, and increase in good support from educational institutions and training of human resources.

Human resources at the SME level can affect competitiveness through the quality of products and services provided, the ability to produce added value, quality management practices, attitudes towards new organizational culture etc. (Ceptureanu, 2015). Wu and Parkvithee (2017) found that several major macroenvironmental factors that influence the competitiveness of SME companies in China include market competition, the legal and political environment, and the social and cultural environment including the language used to communicate with consumers. Ratnasari et al. (2019) state that several factors that influence the improvement of the competitiveness of Eastern Indonesian SMEs are the availability and condition of the business environment, business capability, business performance, policy and infrastructure, research and technology, and external support.

The key performance indicators at the institutional and marketing level are; 1) increase in marketing, institutional and partner networks, 2) increase in government and private assistance for the development of SMEs, and 3) increase in the marketing area of apple chips outside Malang Raya Increasing the ability to conduct product sales promotion activities. Results indicator key performance then inserted into the pillar house models. The house model pillar for enhancing the competitiveness of apple chip SMEs in Malang Raya is shown in Figure 3.

Figure 3 shows that the house model consists of a roof as a vision where the vision in this study is to improve the competitiveness of apple chip crises, the pillars as the main key to achieve this vision consist of products, human resources and marketing institutions. While the foundation in the form of supporting behavior is government policies and regulations in facilitating SMEs in terms of licensing and product safety, so as to

Table 4. Key performance indicators for improving the competitiveness of apple chip SMEs in Malang Raya

\begin{tabular}{|c|c|c|}
\hline Strategic target & Triggers key performance indicators & Key performance indicator results \\
\hline \multirow{4}{*}{ Product Repair } & Product quality & Increased product quality \\
\hline & Product price & Competitive product prices with competitors \\
\hline & & Increased customer satisfaction and loyalty \\
\hline & Consumer satisfaction and loyalty & \\
\hline \multirow{4}{*}{ HR Improvement } & Development of employee skills & Increased employee skills \\
\hline & Increased achievement & Increased achievements both personal and institutional \\
\hline & & Increased teamwork ability to improve SME income \\
\hline & Improved teamwork & \\
\hline \multirow{7}{*}{$\begin{array}{l}\text { Institutional and } \\
\text { marketing }\end{array}$} & Support education and training institutions & $\begin{array}{l}\text { Increased support from both educational and training } \\
\text { institutions for HR }\end{array}$ \\
\hline & & Increased marketing, institutional and partner networks. \\
\hline & Marketing and institutional networks & Increased government and private assistance for the \\
\hline & Government and private assistance & Increased marketing area for apple chips outside of Malang \\
\hline & & Increased ability to conduct product sales promotion activities \\
\hline & Expansion of marketing territory & \\
\hline & Promotion & \\
\hline
\end{tabular}




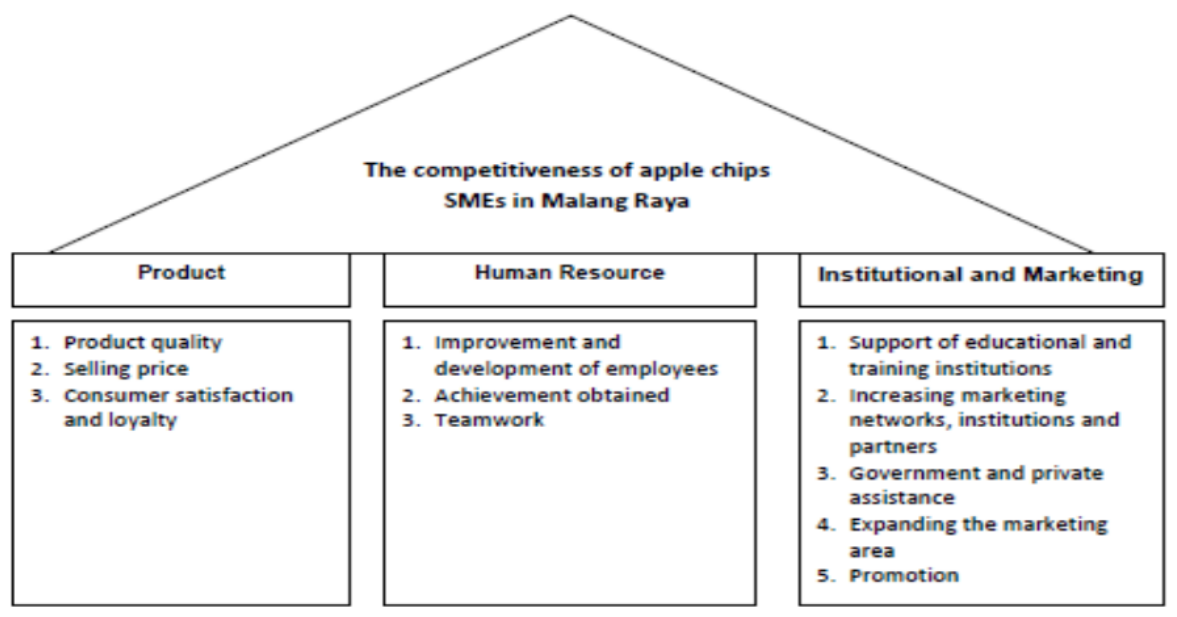

Government policies and regulations in facilitating SMEs in terms of licensing and product safety, so as to increase product competitiveness

Figure 3. The house model pillar increases the competitiveness of apple chip SMEs in Malang Raya

increase product competitiveness.

\section{Conclusion}

The results of the SWOT analysis of the business position of apple chip SMEs are in quadrant 1, namely, strength is greater than weakness. SMEs in this position is deemed very profitable because they have opportunities and strengths, so there needs to be an emphasis on SO strategy. SO strategy, the best strategy for using force to take advantage of opportunities is; 1) increasing the quality of apple chips, 2) increasing the variety of apple chip products, 3 ) extending the validity period of the home industry production permits and halal certificates if they have expired, and 4) increasing the amount of apple chip production. Determination of a strategy to increase competitiveness using the house model method results in product variables being the first priority with a weight of 0.726 , HR improvement occupies the second priority with a weight of 0.198 , while marketing institutions in the third priority with a weight of 0.076 .

\section{Conflict of interest}

The authors hereby declare no conflict of interest.

\section{Acknowledgments}

We would like to thank Department of Agro Industrial Technology, Faculty of Agricultural Technology, University of Brawijaya and Nurul Jadid University.

\section{References}

Ali, A., Xiaoling, G., Sherwani, M. and Ali, A. (2017). Factors affecting Halal meat purchase intention: evidence from international muslim students in
China. British Food Journal, 119(3), 527-541. https://doi.org/10.1108/BFJ-10-2016-0455

Ananda, M.S., Sukmawati, A., Syamsun, M. and Ali, N.A. (2016). Pengembangan model peningkatan kompetensi pekerja domestik Indonesia di Malaysia. Journal of Technology Management, 15(3), 262-278. [In Bahasa Indonesia]. https://doi.org/10.12695/ jmt.2016.15.3.4

Anatan, L. (2010). Pengaruh implementasi praktikpraktik manajemen rantai pasokan terhadap kinerja rantai pasok dan keunggulan kompetitif. Karisma, 4 (2), 106-117. [In Bahasa Indonesia].

Astuti, R., Thessalona, I. and Setiyawan, D. T. (2020). The product quality improvement: an example from a rice milling in Indonesia. IOP Conference Series: Earth and Environmental Science, 515, 012005

Bahri, S. (2012). The effect of environmental dynamics toward the companies competitiveness (Case Study at Manufacturing Industries in South Sulawesi). Jurnal Analisis, 1(2), 190-200.

Bohari, A.M., Cheng, W.H. and Fuad, N. (2013). An analysis on the competitiveness of halal food industry in Malaysia: an approach of SWOT and ICT strategy. Geografia: Malaysian Journal of Society and Space, 9(1), 1-11.

Canny, I.U. (2014). Measuring the mediating role of dining experience attributes on customer satisfaction and its impact on behavioral intentions of casual dining restaurant in Jakarta. International Journal of Innovation, Management and Technology, 5(1), 2529. https://doi.org/10.7763/IJIMT.2014.V5.480

Ceptureanu, S.I. (2015). Competitiveness of SMES. Business Excellence and Management Review, 5(2), 55-67.

Cunningham, L.X. and Rowley, C. (2007). Human resource management in Chinese small and medium enterprises. Personnel Review, 36(3), 415-439. 
https://doi.org/10.1108/00483480710731356

Evalia, N.A. (2015). Strategi pengembangan agroindustry gula semut aren. Jurnal Manajemen and Agribisnis, 12(1), 57-67. [In Bahasa Indonesia]. https://doi.org/10.17358/JMA.12.1.57

Gagić, S., Tešanović, D. and Jovičić, A. (2013). The vital components of restaurant quality that affect guest satisfaction. Turizam, 17(4), 166-176. https:// doi.org/10.5937/Turizam1304166G

Gürel, E. and Tat, M. (2017). SWOT analysis: a theoretical review. Journal of International Social Research, 10(51), 994-1001. https:// doi.org/10.17719/jisr.2017.1832

Hansen, J.R. (2016). Price satisfaction and producer loyalty: the role of mediators in business to business relationships in Kenyan mango supply chain. British Food Journal, 118(5), 1067-1084. https:// doi.org/10.1108/BFJ-09-2015-0319

Horovitz, J. and Ohlsson-Corboz, A.V. (2007). A dream with a deadline: turning strategy into action. London, United Kingdom: Pearson Education.

Idar, R. and Mahmood, R. (2011). Entrepreneurial and market orientation relationships to performance: The SME perspective. Interdisciplinary Review of Economics and Management, 1(2), 1-8.

Kalpande, S.D., Gupta, R.C. and Dandekar, M.D. (2015). Study of SMEs for TQM implementation-SWOT analysis. International Journal of Engineering and Industrial Management, 2, 167-177.

Mallini, L., Dania, W.A.P. and Putri, S.A. (2015). Peramalan permintaan dengan pendekatan marketing mix pada produk keripik apel menggunakan metode jaringan syaraf tiruan. Industria: Jurnal Teknologi dan Manajemen Agroindustri, 4(1), 21-30. [In Bahasa Indonesia].

Moi, M.R., Noor, M.A.M. and Ismail, M.A. (2016). Competitiveness of Halal Industry in Maghreb Countries. Global Journal Al-Thaqafah, 6(1), 61-67. https://doi.org/10.7187/GJAT10320160601

Munawir, H., Sufa, M.F. and Wigaringtyas, L.D. (2016). Strategi peningkatan kinerja rantai pasok ukm batik dengan supply chain operation reference (SCOR) presented at the IENACO (Industrial Engineering National Conference) 2016. Indonesia: Universitas Muhammadiyah Surakarta. [In Bahasa Indonesia].

Nasir, A., Ahmed, M.A., Nazir, I., Zafar, H. and Zahid, Z. (2014). Impact of different determinants on customer's satisfaction level (A case of fast food restaurant). International Journal of Business and Management Invention, 3(9), 32-40.

Nasirun, N., Noor, S.M., Sultan, A.A. and Haniffiza, W.M.H.W.M. (2019). Role of marketing mix and halal certificate towards purchase intention of agro based products. International Journal, 2(7), 37-46.

Osman, Z. and Sentosa, I. (2013). A study of mediating effect of trust on customer satisfaction and customer loyalty relationship in Malaysian rural tourism. European Journal of Tourism Research, 6(2), 192206.

Porter, M. (2003). Strategi bersaing: Teknik menganalisis industry dan pesaing. Jakarta: Penerbit Erlangga. [In Bahasa Indonesia].

Purwidianti, W. and Rahayu, T.S.M. (2017). Pengaruh faktor internal dan eksternal terhadap kinerja usaha industri kecil dan menengah di Purwokerto Utara. Kinerja, 19(2), 151-161. [In Bahasa Indonesia]. https://doi.org/10.24002/kinerja.v19i2.541

Rahaju, J. and Muhandoyo, M. (2014). Dampak perubahan iklim terhadap usaha apel di Kecamatan Poncokusumo Kabupaten Malang. Agromix, 5(1), 19. [In Bahasa Indonesia]. https://doi.org/10.35891/ agx.v5i1.697

Rangkuti, F. (2016). Analisis swot: teknik membedah kasus bisnis. Jakarta: Penerbit Gramedia Pustaka Utama. [In Bahasa Indonesia].

Ratnasari, R.T., Gunawan, S., Rusmita, S.A. and Prasetyo, A. (2019). Halal Food Certification to Improve the Competitiveness of East and Middle Business in Indonesia presented at the 2nd International Conference on Islamic Economics, Business, and Philanthropy (2nd ICIEBP), p. 10441056. Indonesia: Department of Islamic Economics, Faculty of Economics and Business, Universitas Airlangga. https://doi.org/10.18502/kss.v3i13.4266

Sahara, S. and Gyau, A. (2014). Contractual arrangements and commitment in the Indonesian supermarket channel. British Food Journal, 116(5), 765-779. https://doi.org/10.1108/BFJ-03-2012-0070

Santoso, I. (2016). Peran kualitas produk dan layanan, harga dan atmosfer rumah makan cepat saji terhadap keputusan pembelian dan kepuasan konsumen. The Asian Journal of Technology Management, 15(1), 94. [In Bahasa Indonesia].

Singh, R.K., Garg, S.K. and Deshmukh, S.G. (2008). Strategy development by SMEs for competitiveness: a review. Benchmark: An International Journal, 15 (5), 525-547. https:// doi.org/10.1108/14635770810903132

Soseco, T. (2015). Pusat pertumbuhan di kota malang: potensi dan permasalahan. Jurnal Ekonomi dan Studi Pembangunan, 3(1), 1-8. [In Bahasa Indonesia].

Syam, Q.N., Santoso, I. and Putri, S.A. (2014). Pengendalian persediaan apel untuk produksi minuman sari apel dengan pendekatan supply chain 
management (studikasus di Brosem Malang). Fakultas Teknologi Pertanian. Indonesia: Universitas Brawijaya, MSc. Thesis [In Bahasa Indonesia].

Tsurayya, S. and Kartika, L. (2015). Kelembagaan dan strategi peningkatan daya saing komoditas cabai Kapupaten Garut.Jurnal Manajemen and Agribisnis, 12(1), 1-13. [In Bahasa Indonesia]. https:// doi.org/10.17358/JMA.12.1.1

Um, J., Lyons, A., Lam, H.K., Cheng, T.C.E. and Dominguez-Pery, C. (2017). Product variety management and supply chain performance: A capability perspective on their relationships and competitiveness implications. International Journal of Production Economics, 187, 15-26. https:// doi.org/10.1016/j.ijpe.2017.02.005

Wati, N.K., Shaleh, C. and Wachid, A. (2014). Strategi pengembangan industri pengolahan apel berbasis ekonomi lokal (studi pada dinas koperasi, ukm, perindustrian dan perdagangan Kota Batu). Jurnal Administrasi Publik, 2(1), 102-108. [In Bahasa Indonesia].

Wiesner, R. and Millett, B. (2012). Strategic approaches in Australian SMEs: deliberate or emergent? Journal of Management and Organization, 18(1), 98-122. https://doi.org/10.1017/S1833367200001097

Wiid, J., Cant, M. and Holtzhausen, L. (2015). SWOT analysis in the small business sector of South Africa. Corporate Ownership and Control, 13(1), 446-453. https://doi.org/10.22495/cocv13i1c4p3

$\mathrm{Wu}$, W. and Parkvithee, N. (2017). Promoting international competitiveness for small and mediumsized enterprises (SMEs): A case study of Chinese SMEs in Thailand. International Review of Management and Marketing, 7(3), 320-330. 